METALLURGY AND FOUNDRY ENGINEERING - Vol. 38, 2012, No. 2

http://dx.doi.org/10.7494/mafe.2012.38.2.163

\author{
Jadwiga Kamińska*, Angelika Kmita*, Joanna Kolczyk*, \\ Sylwia Żymankowska-Kumon**
}

\title{
RECLAMATION OF SPEND MOULDING SANDS WITH THE CARBOPHEN 8178 RESIN
}

\section{INTRODUCTION}

Reclamation of spent moulding and core sands can be defined as a technological conversion of used refractory moulding materials with the aim of their reusing in a production of casting moulds and cores. A reclamation treatment is understood as a complex of operations, to which spent moulding sands are subjected one by one. The reclamation process comprises the preliminary sand preparation for the reclamation (primary reclamation) and the secondary reclamation, leading to the final product, it means to the regeneration of at least one of the components of spent sands of properties very similar to the ones of the fresh component. Such reclaimed component can be reused for the moulds and core production $[1,2]$.

Castings production in Poland is at the level of app. 1000000 ton/year [3]. It is assumed that production of 1 ton of rough casting generates app. 1 ton of wastes, it means spent sands which are not suitable for reusing without the reclamation treatment proper for the given kind of a moulding sand. The reclamation level of spent sands in the Polish Foundry plants equals app. 20\%. The remaining part is either used outside the foundry industry or is transported to the dumping grounds [4]. Maintaining standards and environment protection rules forces currently the casting producers to minimise production wastes, including spent moulding and core sands. The reclamation of spent sands is one of the ways of this task realisation.

The notion: spent sand reclaimability is understood as the easiness of the regeneration of its wholesome components.

Spent moulding and core sands are considered by the foundry practice to be especially difficult for the reclamation. Reclamation effects of these sands, are based on several instrumental examinations, allowing to assess a technological suitability of a matrix reclaimed

* M.Sc., ** Ph.D.: AGH University of Science and Technology, Faculty of Foundry Engineering, Krakow, Poland; e-mail: kaminska@agh.edu.pl 
in the given device. When mechanical reclaimers of various influence mechanisms are used, it is very difficult to perform the comparative assessment of reclaimability of various sands since the applied system - leading to the liberation of matrix grains from binding material coatings - undergoes a change $[5,6]$. Thus, the development of the method allowing the comparison of sands of a different reclaiming ability seems to be justified.

Apart from spent sands with alkaline phenolic resin (alpha-set process), sands with water-glass (Foster process) and sands with strongly alkaline resins bonded by means of $\mathrm{CO}_{2}$ are considered difficult for reclamation [7].

\section{EXPERIMENTAL STAND}

Experimental investigations, assessing the spent sands reclaiming ability, were performed by means of the special tester, in which rotating impact-abrasive elements were applied. Rotational speed of these elements can be regulated in a range 460-1680 rpm. The feature which is distinguishing the applied tester from the ones used up to date, is a possibility of performing the reclamation treatment at a skew placement of the whole apparatus, which helps an internal sand circulation. The deviation range from the vertical position equals from $0^{\circ}$ to $6^{\circ}$. The pictorial diagrams of the applied apparatus in case of operating in a vertical position and at a deviation by angle $\alpha$, are presented in Figure $1[8,9]$.
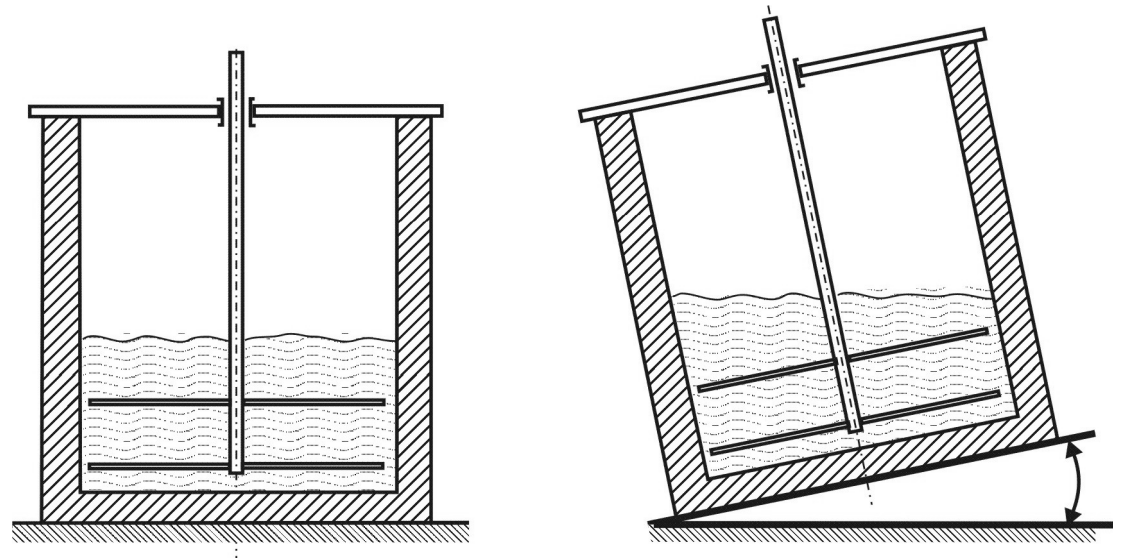

Fig. 1. Schematic presentation of the testing apparatus applied for the reclamation

\section{METHODOLOGY OF INVESTIGATIONS}

The reclamation results of spent moulding sands originated from the alpha-set technology are presented in the paper. Not burned sands were used in the reclamation process since these sands constitute more difficult conditions for the reclamation than burned sands.

The reclaimability was tested for a spent sand with the Carbophen 8178 resin, hardened by $\mathrm{CO}_{2}$. 
Sands were prepared in the laboratory ribbon mixer, and this preparation was carried out in accordance with the resin producer recommendations.

The phenolic resol Carbophen 8178 resin was used and the moulding sand composition was:

- Dry, high-silica sand 100 parts by weight,

- Carbophen 8178 resin $\quad 3.0$ parts by weight.

After the preparation the sands were hardened for 24 hours and then the primary reclamation process was applied. The schematic presentation of this process is graphically shown in Figure 2. The reclamation results obtained at the average speed being $700 \mathrm{rpm}$ are included in the paper. The secondary reclamation process is presented schematically in Figure 3.

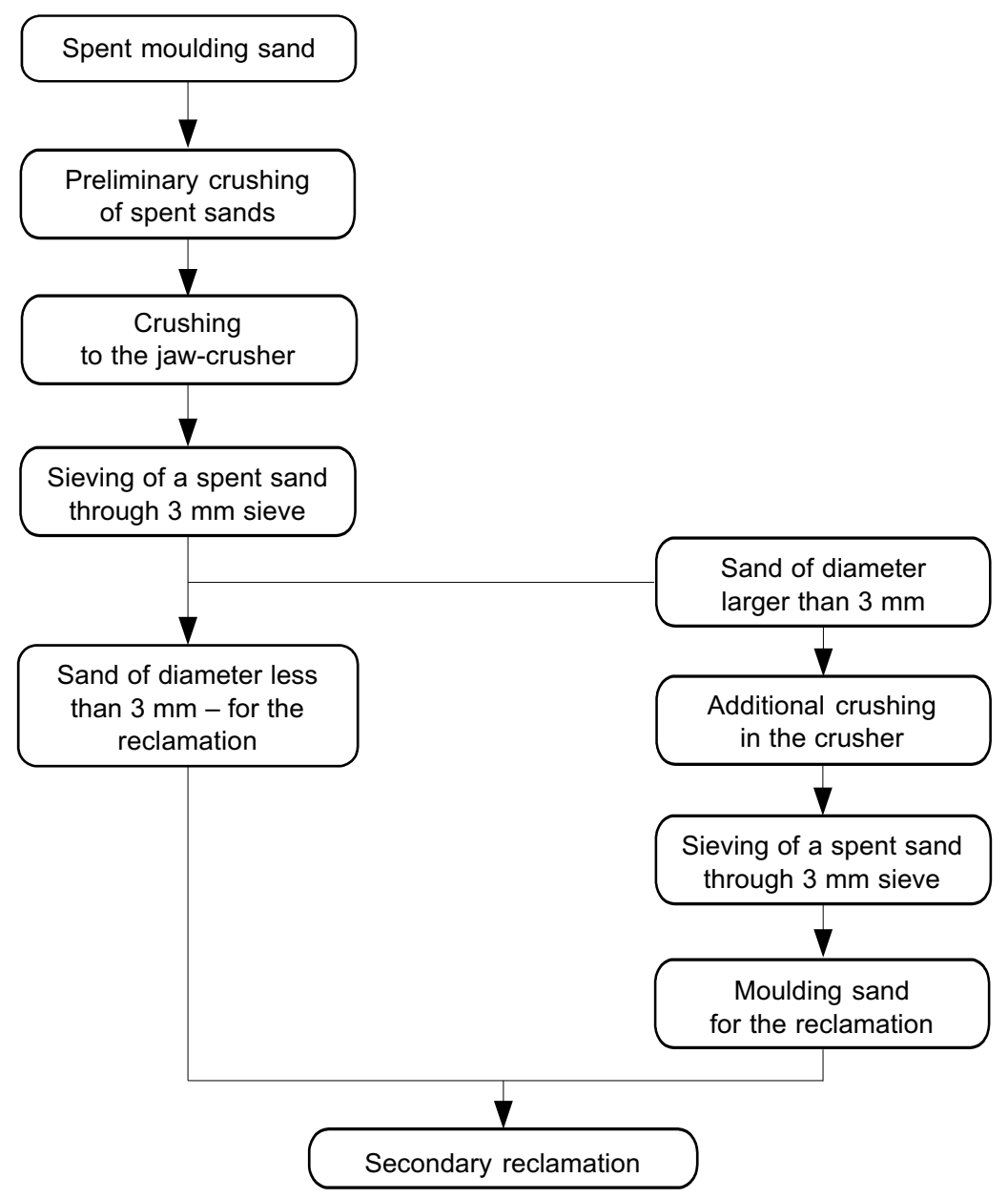

Fig. 2. Schematic presentation of the preliminary reclamation process of tested sand 


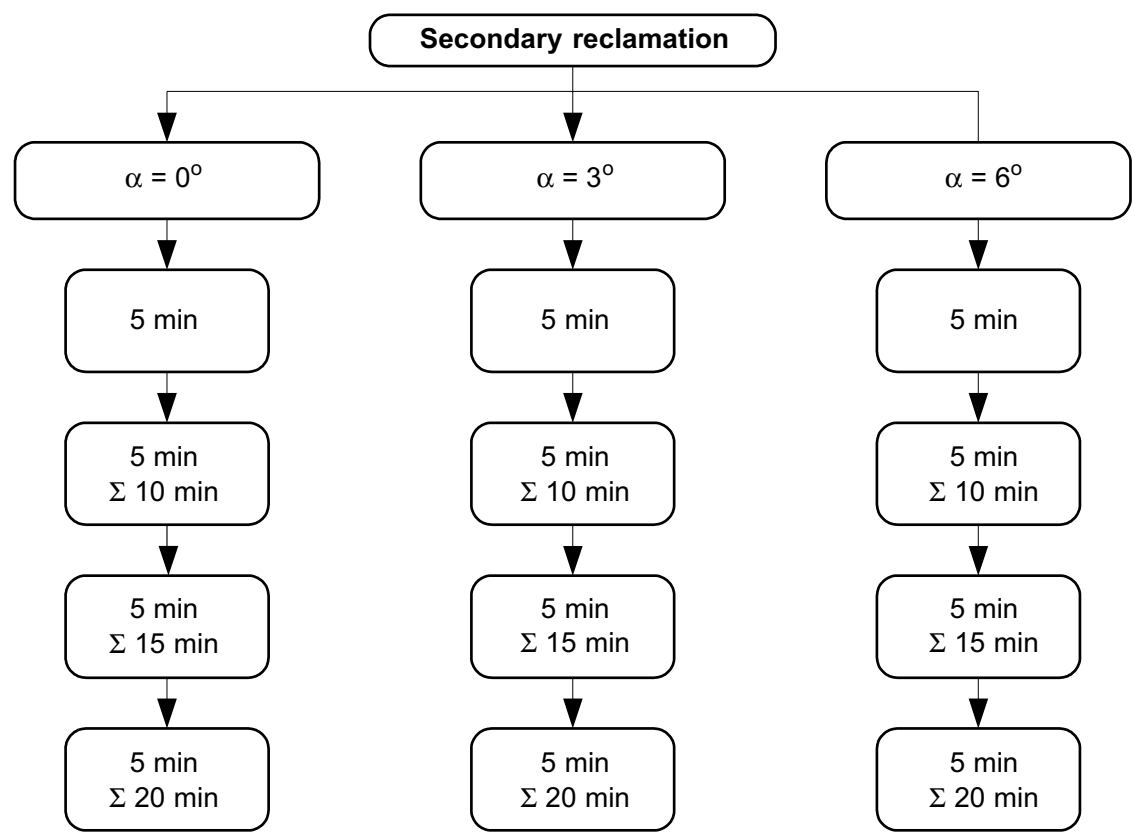

Fig. 3. Schematic presentation of the secondary reclamation process applied in examinations

\section{RESULTS}

\subsection{Sieve analysis results}

A sieve analysis performed for sands after the reclamation, but without any dust extraction, indicates clearly that along with an increase of the reclamation time the amount of dust fractions in the reclaimed materials also increases. This testifies that elementary operations such as rubbing, grinding and crushing occur in the reclaimer, causing a systematic decrease of spent binder coatings on matrix grains.

Changes of the average diameter of spent sand grains after the reclamation, performed in the tester, are presented in Figure 4. Comparing data shown in this figure one can notice a decrease of $d_{L}$ value as the reclamation time increases. For the reclamation carried out at a speed of $700 \mathrm{rpm}$ the reclamation effect - measured by the decrease of the average grain diameter $d_{L}$ - is larger and does not depend on the reclaimer position.

An influence of the reclamation time on the theoretical specific surface, St, during the mechanical reclamation in the tester is presented in Figure 5. It results from the diagram that the longer reclamation time the larger theoretical surface. The increase of the theoretical specific surface is the result of the decrease of the average grain diameter of the reclaimed grains. 


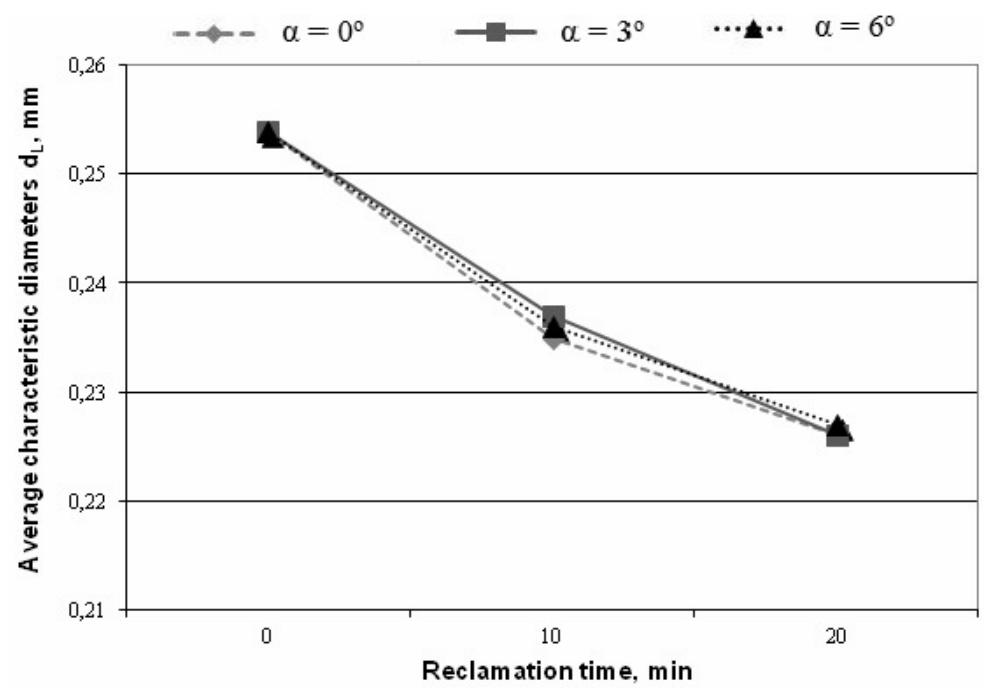

Fig. 4. Change of the average characteristic diameters $d_{L}$ as a function of the reclamation time

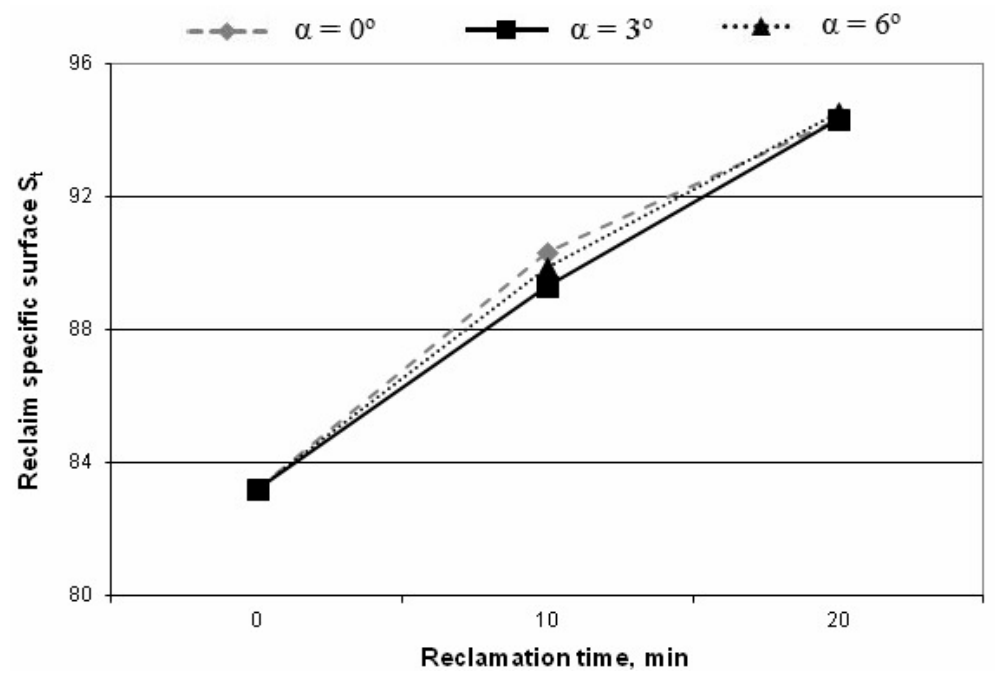

Fig. 5. Change of the reclaim specific surface $S_{t}$ as a function of the reclamation time

\subsection{Ignition loss}

Ignition loss tests of the obtained reclaimed materials were performed, after each stage of investigations. The determination of ignition losses was carried out for samples after the complete reclamation process, it means after the final separation of the powdery fraction. The ignition loss results are shown in Figure 6. Ignition loss values carry the information on the amount of a binder remaining on the matrix after the reclamation process. 


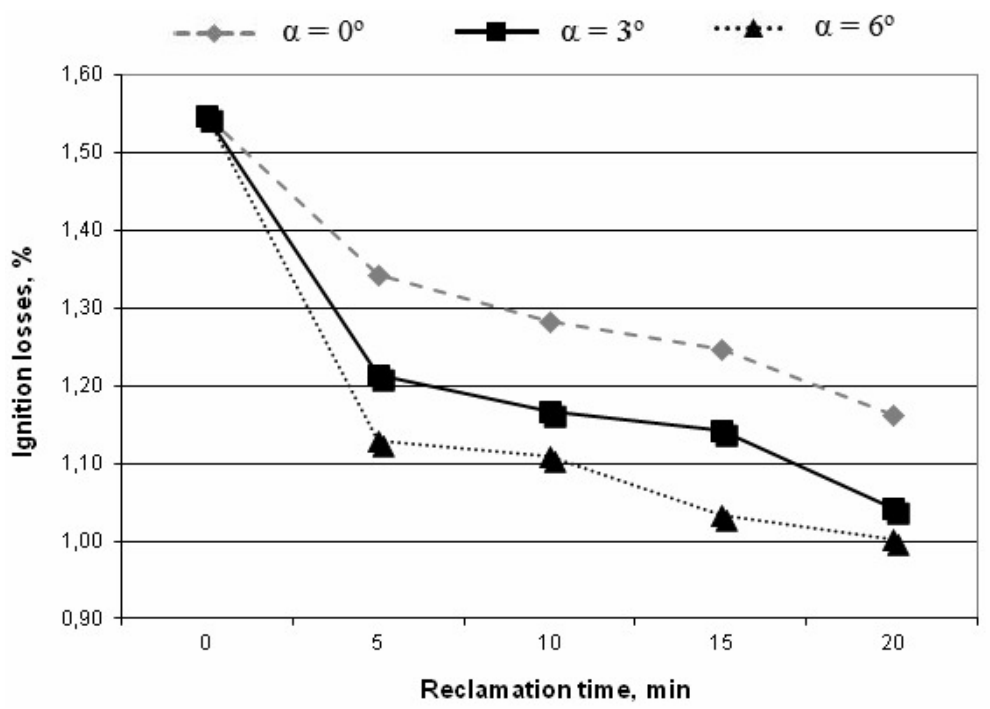

Fig. 6. Ignition losses of reclaimed sands as a function of the reclamation time

The analysis of Figure 6 reveals that ignition losses of the reclaims, being after the mechanical reclamation process, decrease when the reclamation time is longer. This indicates more accurate removal of the binder coating. The average ignition loss decrease with the reclamation time equals app. $9 \%$, while the highest, of app. $13 \%$ is obtained at the reclaimer position $3\left(\alpha=6^{\circ}\right)$ after 15 and 20 minutes.

\subsection{Acid demand $Z_{K}$}

The results of acid demand values $\mathrm{Z}_{\mathrm{K}}$ as the time of the reclamation process increases are presented in Figure 7. The experimental data indicate that an increase of the reclamation treatment time leads to a decrease of the acid demand value. The smallest $Z_{K}$ value at $700 \mathrm{rpm}$ is obtained at the position $3\left(\alpha=6^{\circ}\right)$. The value of this factor, after the reclamation process is by $20 \%$ lower than $Z_{K}$ of sands before the reclamation (acid demand of a spent sand before the reclamation process was 34.5).

\subsection{Results of the surface morphology examinations}

Examinations of the surface morphology of the reclaimed sand (Fig. 8) was performed by means of the optical microscope EDUKO, at a magnification of $40 \times$.

Characterising the obtained photographs it can be stated, that the best reclamation effects are obtained in case of the average position value (Fig. 8b). The matrix obtained at such position has more spherical grains and is more homogeneous, due to which it is fully suitable for reusing.

However, the surface morphology examined by means of a low quality microscope is one of the least reliable assessment method of the reclaimed material quality, since it is based only on a visual impression and not on laboratory examinations. 


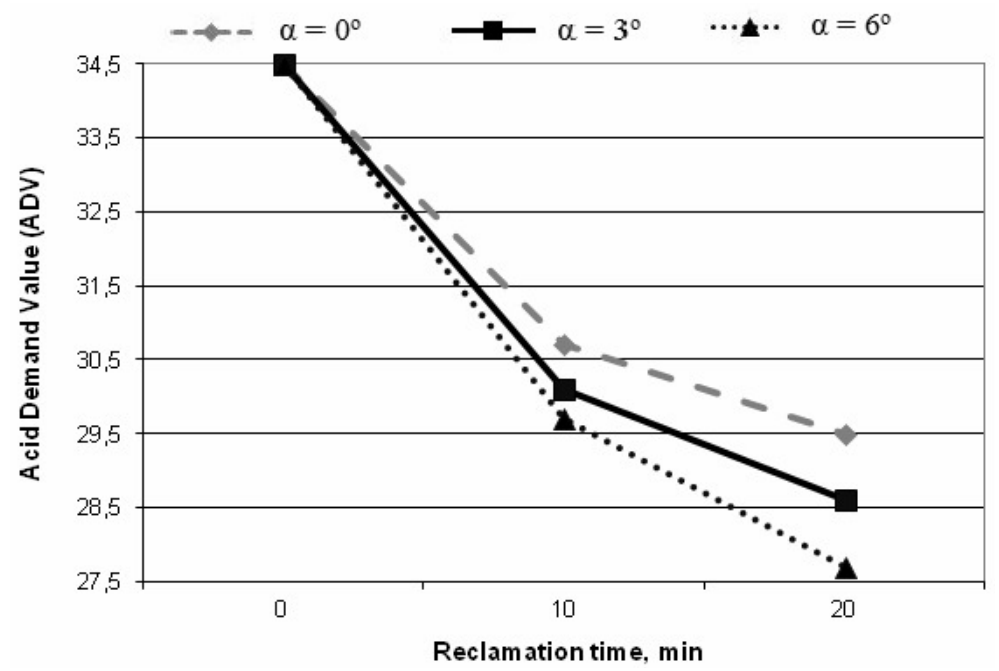

Fig. 7. Acid Demand Value (ADV) as a function of the reclamation time

a)

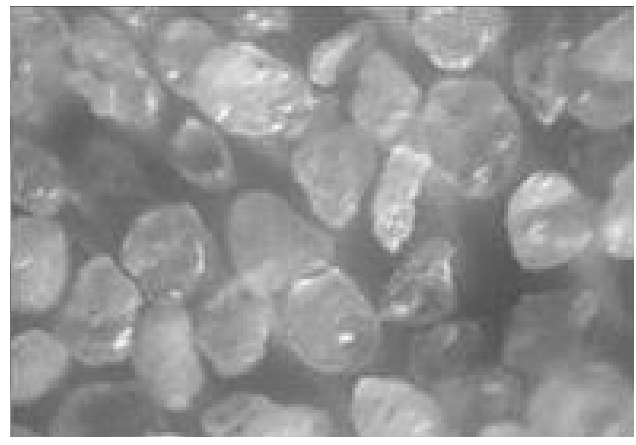

c)

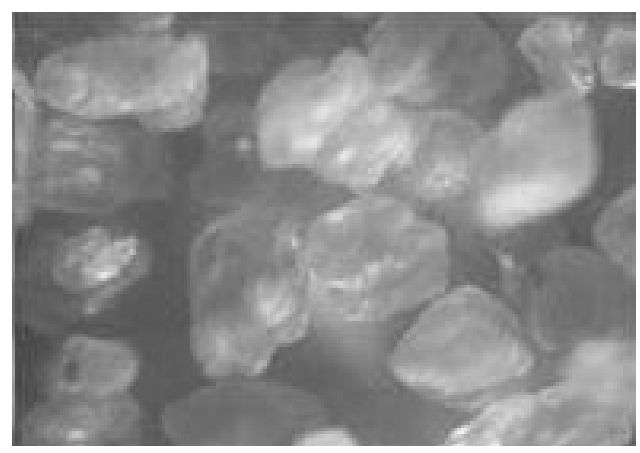

b)

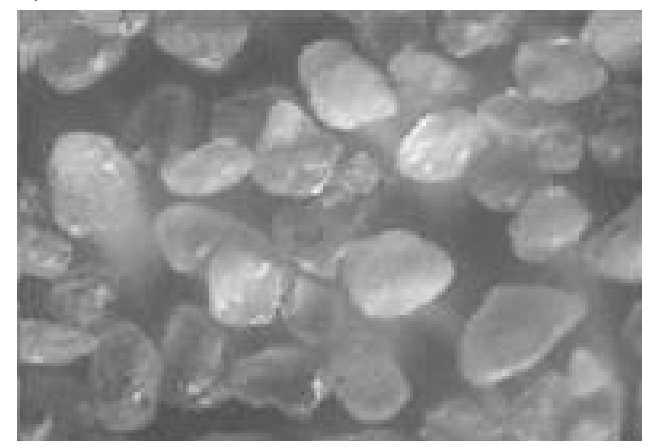

Fig. 8. The surface morphology of reclaimed sands, magnification $40 \times$ : a) $\alpha=0^{o}$; b) $\alpha=3^{o}$; c) $\alpha=6^{\circ}$ 


\section{CONCLUSIONS}

The investigations confirmed that the ignition loss is the most reliable method of the quality assessment of the reclaimed sand with an organic binder. The maximum reclamation degree of this sand obtained in the mechanical reclamation process, measured by the ignition loss value, was $35 \%$. This reclamation degree was obtained at the testing apparatus rotational speed being $700 \mathrm{rpm}$, at inclination of $6^{\circ}$ and the maximum reclamation time of 20 minutes.

On the bases of the performed investigations it was found, that as the reclamation time increases the $Z_{K}$ value successively decreases, which indirectly indicates the decrease of a spent binding material amount on matrix grains.

The sieve analysis is a very important element of the reclaim assessment, allowing for the process intensity control eliminating the matrix crushing.

Summarising, on the grounds of the performed investigations it can be stated that the developed testing apparatus enables the reclamation of various kinds of spent moulding sands, including sands from the alpha-set technology, which are difficult for the reclamation.

\section{Acknowledgements}

The study was performed within the 'Dean's Grant' 2012 No.15.11.170.417.

\section{REFERENCES}

[1] Dańko J., Dańko R., Lucarz M.: Procesy i urządzenia do regeneracji osnowy zużytych mas formierskich, Wydawnictwo Naukowe AKAPIT, Kraków, 2007

[2] Dańko R.: Podstawy teoretyczne i technologiczne doboru optymalnych sposobów regeneracji suchej zużytych mas odlewniczych, AGH - Wydział Odlewnictwa, Kraków, 2006 (Ph. D. thesis, unpublished)

[3] Dańko J., Holtzer M. (eds), Możliwości ograniczenia i metod zagospodarowania odpadów z procesów odlewniczych, Wydawnictwo Naukowe AKAPIT, Kraków, 2009

[4] Dańko J., Holtzer M., Dańko R., Grabowska B.: Analiza i struktura odpadów z krajowych odlewni, Archives of Foundry Engineering, 2 [B] (2008), 5-9

[5] Luksa I.: Badanie regenerowalności zużytej masy rdzeniowej z żywicą CARBOPHEN 8178, AGH Wydział Odlewnictwa, Kraków, 2009 (M. Sc. thesis, unpublished)

[6] Dańko R., Kamińska J.: Procesy regeneracji zużytych mas formierskich i rdzeniowych, Sesje Studenckich Kół Naukowych, Kraków, 2 (2009), 253

[7] Dańko R., Kamińska J.: Assessment of reclamation of used sands from the alpha-set technology in the testing apparatus, Archives of Foundry Engineering, 9 (2009) 1, 33-37

[8] Dańko R.: Innovative developments in sand reclamation technologies, Metalurgija - Metallurgy, 50 (2011) 2, 93-96

[9] Dańko R.: Analysis of effectiveness of used sands reclamation treatment - in various technological devices, Archives of Foundry Engineering, 9 (2009) 4, 31-36

[10] Kamińska J., Dańko J.: Investigation of the selected properties of dusts from the reclamation of spent sands with bentonite, Archives of Foundry Engineering, 11 (2011) 4, 177-181 